\title{
Inter-Firm Relationships in the Telecommunications Industry: Characteristics and Typology
}

\author{
Noriaki Shiraishi \\ Tokyo Institute of Technology \\ E-Mail: shiraishi-n@pro.odn.ne.jp \\ Junichi Iijima \\ Tokyo Institute of Technology \\ E-Mail: iijima.j.aa@m.titech.ac.jp
}

\begin{abstract}
This paper discusses the characteristics and formation of inter-firm relationships in the telecommunications industry. The formation and partner selection are key issues for managers arranging inter-firm relationships. We focus on inter-firm relationships conducted by the telecommunications carriers and discuss the characteristics of the industry and possible or preferred formations and propose an analytical framework for inter-firm relationships in the industry. The discussion and proposed framework are validated by actual observed inter-firm relationships. We observed that major telecommunications firms choose equity-based relationships rather than other types and we show a framework that can help people to recognize strategic directions for preparing a valuation of inter-firm relationships in the industry.
\end{abstract}

Keywords: Telecommunications, Strategic Alliances, M\&A, Typology

\section{INTRODUCTION}

This research focuses on inter-firm relationships in the telecommunications industry that seem to have distinct characteristics and still have scope for analysis and discussion. And this research aims to provide a useful analytical framework for developing inter-firm strategies through discussions of characteristics of the industry.

Like companies in other industries, telecommunications firms have formed a considerable number of relationships such as equity arrangements, including joint ventures and M\&As aimed to enhance market competitiveness. Such relationships had 
become common by the mid-1980s in the United States; other industrialized countries soon followed this trend with the progress of deregulation in the 1990s (Joshi, Kashlak, and Sherman,1998; Trillas, 2002). Managers involved in the telecommunications industry must therefore consider forming relationships of these kinds as one of their top-priority strategic activities. It is important for both managers and scholars to research and discuss these relationships. In this paper, we call these arrangements inter-firm relationships, based on the definition provided by Yoshino and Rangan (1995).

Researchers have frequently analyzed issues related to strategic activities in the telecommunications industry, with a focus on specific cases of inter-firm relationships. For example, Wilcox, Chang, and Grover (2001) discussed the effect of M\&A by U.S.-based carriers, Trillas (2002) analyzed European carriers, Baroncelli (1998) studied AOL-Time Warner, and Faulhaber (2002) discussed Telecom Italia. Other scholars have also studied the regulatory environment of the industry in specific countries and areas (e.g., Hudson, 2004). These researchers concentrated on strategic alliances and M\&A conducted by telecommunications firms. Attention was not limited to alliances and M\&A within the industry but was also directed toward alliances with firms in other industries, such as equipment manufacturing.

Many researchers have also discussed industries other than telecommunications, with useful analyses and frameworks for understanding and establishing strategies (Gudmundsson \& Rhoades, 2001; Hill, 1997; Rhodes \& Lush, 1997; Yasuda, 2005; Achilladelis \& Antonakis, 2001; Amesse, Latour, Rebolledo and Seguin-Dulude, 2004). These studies focused on inter-firm relationships within each industry. The frameworks and methodologies used by these authors for categorizing alliances are useful in identifying the characteristics of each industry.

However, it is difficult to find research dealing with inter-firm relationships within the telecommunications industry that discusses typology and alliance strategies. In addition, it can be recognized that discussions of inter-firm relationships in the telecommunications industry have usually not distinguished strategic alliances from M\&A (Oh, 1996; Chan-Olmsted \& Jamison, 2001; Curwen, 2001; Jamison \& Chan-Olmsted, 2002).

As will be discussed in the following section, it is important to note that when many major telecommunications carriers choose new relationships with other carriers, they seem to select M\&A or equity-based relationships as strategic activities rather than entering into strategic alliances to expand their competitive edge. These tendencies imply that there exists a common understanding of the characteristics of 
the telecommunications industry that provides a concept of inter-firm relationship specific to the industry. Based on the recognition of such circumstances, we maintain that it is very important for managers and scholars involved in the telecommunications industry to identify the characteristics of that industry. They should analyze alliances and M\&A using the comparative framework of analysis utilized in other industries.

In this study, we attempted to identify the characteristics of the telecommunications industry that may be correlated with telecom regulations and offer a framework for understanding inter-firm relationships in the industry that will help managers and scholars recognize strategic directions for each firm. For this purpose, we focused on inter-firm relationships conducted by the telecommunications carriers in OECD countries and explored the characteristics of the industry itself in an effort to clarify those characteristics. Therefore, we did not focus on relationships conducted by firms in adjacent industries to telecommunications industry. Those types of relationships have different aspects, as discussed by Wilcox et al. (2001) that include relationships conducted by electronics manufacturing firms.

We analyze and discuss inter-firm relationships conducted within the terms of deregulation in industrialized countries after the 1980s to early 2000s. We then cover the era of recent regulatory change, which has featured legislation such as the Telecommunications Act of 1996 in the United States and similar changes in other countries.

Next section reviews discussions on the telecommunications industry and regulatory changes in the industry and examines the characteristics of the industry that affect managers' strategic decisions. And the third sections discuss the formations of inter-firm relationships in the telecommunications industry that distinguish these relationships from those in other industries Forth section outlines and proposes a typology of inter-firm relationships in the industry and proposes an analytical framework for evaluating the direction of telecommunications firms' strategic activities. It also provides notes about the adaptability of the proposed framework. The last section presents conclusions and mentions remaining issues for further research.

\section{CHARACTERISTICS OF THE TELECOMMUNICATION INDUSTRY}

This section addresses the distinguishing characteristics of the telecommunications industry and strategies chosen by firms. Scholars have mainly analyzed the industry's characteristics from economic and regulatory environment standpoints (Brock, 1998; Kahn, 1997; Laffont \& Tirole, 2001; Vogelsang \& Mitchell, 1997). These researchers identified the scale and scope, network externality, 
bottleneck monopolies, and correlated regulatory systems as distinctive features of the industry. Kahn (1997) and Vogelsang \& Mitchell (1997) used a definition of economiess of scale and scope to argue that the production of telecommunications services and the costs for providing services will be lower if a firm acquires a considerable scale of business and substantial product lines. These scholars also suggested that network externality makes a fully interconnected network the most efficient supply structure.

One of the most significant characteristics of the industry is the existence of the "bottleneck” (Laffont \& Tirole, 2001; Vogelsang \& Mitchell, 1997). Telecommunications services are generally standardized and common to almost all carriers, with no technological alternatives available to competitive telecommunications carriers seeking to acquire some of the bottlenecked resources. In the past, telecommunications services were provided by secure monopolies or private regulated corporations in most countries. Even after deregulation and privatization, the market structure has been such that long-distance telecommunications services have to utilize the loops, switches, and interoffice transmission facilities of local exchange carriers; in this case, the local loop is identified as a bottleneck. Given this situation, interconnection between telecommunications and incumbent carriers is one of the most important factors in assuring fair competition in the industry. In addition, the structure of telecommunications has led to regulatory systems that differ from those of other industries. Brock (1998) provided an alternate description of the condition that highlights the economic characteristics of the industry and identified three characteristics - network externality, revenue sharing between firms participating in a telephone call through network interconnection, and the structure of the telephone industry itself — as a vertically integrated effective monopoly controlled by a dominant firm.

With regard to the regulatory issue, Crandall (1996) provided a convincing argument that a complete deregulation might not be feasible or easy to accomplish, and Styliadou (1997) wrote from a similar standpoint. Joshi et al. (1998) and Laffont \& Tirole (2001) proposed the significant view that the industry is clearly split into three groups: (a) firms providing local connectivity; (b) firms offering long-distance services, including international calling; and (c) firms offering cellular or paging services. This definition sheds light on the argument between carriers and regulatory bodies that led to the AT\&T divestiture undertaken in 1984. Although the above typology of firms in the industry is based on conditions in the United States, many regulators in other countries have introduced similar concepts and systems. As 
illustrated in the researchers' discussions, two characteristics of the industry seem to affect a firm's strategic behavior and choices of inter-firm relationships.

The first characteristic is the nature of telecommunications services. As with other public utility businesses, the economies of scale and scope in providing services leads the telecommunications market into a natural monopoly (Vogelsang \& Mitchell, 1997). In particular, researchers have generally agreed that local telephone service is a natural monopoly (Kahn, 1997). This tendency toward monopolies is correlated with two other aspects of the industry. One is that telecommunications firms have to provide standardized services and the other is that network externality exists. In such an environment, a natural monopoly, accompanied by a fully interconnected network, is the most efficient and competitive business decision (Vogelsang \& Mitchell, 1997). Therefore, firms in the industry have naturally been interested in expanding their networks or their telecommunications services.

The second characteristic of the industry that affects a firm's strategic behavior and its choice of inter-firm relationships is the regulatory system. In the past, the telecommunications market was defined as a combined market-local, long-distance (including or excluding international connectivity), and mobile services. Strict barriers were drawn between individual markets, and firms were legally restricted to services of one type or several of each type. These regulatory systems also set barriers preventing new companies from entering each market and restricting foreign investors.

Starting in the 1980s, regulatory bodies in many countries began to introduce policies for competition into the telecommunications market, resulting in the relaxation of many regulations (Vogelsang \& Mitchell, 1997). In many cases, these policies were introduced into the long-distance and international markets at an early stage and only later introduced into other market segments. Examples of these deregulations include the Federal Communications Commission policy (FCC, 1980), which represents the decision to introduce competition into the long-distance market as a result of the suit by MCI against AT\&T. MCI sought to gain fair interconnection with AT\&T's local networks in the United States from 1974 through 1980, in Japan from the middle of the 1980s, and in EU countries in the 1990s.

It is also important to be aware of subsequent deregulation initiatives such as the Telecommunications Act of 1996 in the United States and further deregulations in the EU, Japan, and other countries. These regulatory changes were - each carrier in a segment of the industry (local, long distance/international and mobile etc.) have been allowed to enter into other segment, and relief of ownership regulations (e.g. 
foreigners ownership) had been brought. By the mid-1990s, these policies had been introduced into almost all categories of the telecommunications industry. This trend of regulatory changes is dramatic; we offer the hypothesis that the regulatory trend affects the alliance strategies of firms in the industry.

The next section discusses the characteristics of inter-firm relationships based on these historical and regulatory aspects, reviewed theories, and industry trends.

\section{INTER-FIRM RELATIONSHIPS IN THE TELECOMMUNICATIONS INDUSTRY}

\section{Categorization of Relationships}

Firms usually enter into strategic alliances, joint ventures, equity investment, or M\&A for the purpose of strengthening their ability to compete. They choose one or more of these alternatives depending on their strategic purposes, market environment, products, and technological capabilities (Doz \& Hamel, 1998). For example, a firm might use M\&A to control a counterpart firm, whereas a strategic alliance is a relationship in which each firm can maintain its independence.

Yoshino and Rangan (1995) and Mocker (1997) defined strategic alliances as inter-firm relationships that two or more independent firms use on a continuing basis to contribute to one or more key strategic goals. The firms share the benefits of their teamwork while remaining independent. Although various kinds of inter-firm relationship exist, the definition provided by Yoshino and Rangan (1995) is one of the most typically referred to categorizations of inter-firm relationships (Figure 1). The next issue, then, is which inter-firm formation should be pursued when managers in the industry hope to strike up relationships with other telecommunications carriers in order to improve their competitiveness within the industry.

The motivations and structures of alliances are often explained by the resource-based view (Das \& Teng, 2000; Peng, 2001; Harrison, Hitt, Hoskisson \& Ireland, 2001) or transaction-cost theory (Hoffmann \& Schlosser, 2001). The former explains an alliance as a means of obtaining additional resources, while the latter defines alliances in terms of the minimization of transaction costs between organizations.

Much research referring to these theories has been conducted on the correlation between alliance formation and various factors. Chen (2003) tried to explain and analyze the factors involved in a firm's choice of alliance form based on six hypotheses, addressing issues such as environment, nationality, and number of 
partners. Garette and Dussauge (2000) also provided a hypothesis and empirical test for the correlation between environment, partner characteristics, and alliance forms. In addition, Schoenberg and Reeves (1999) discussed factors that determine acquisition activities such as regulatory environment, and Hopkins (1999) discussed M\&A motives (strategic, market, economies and personal)

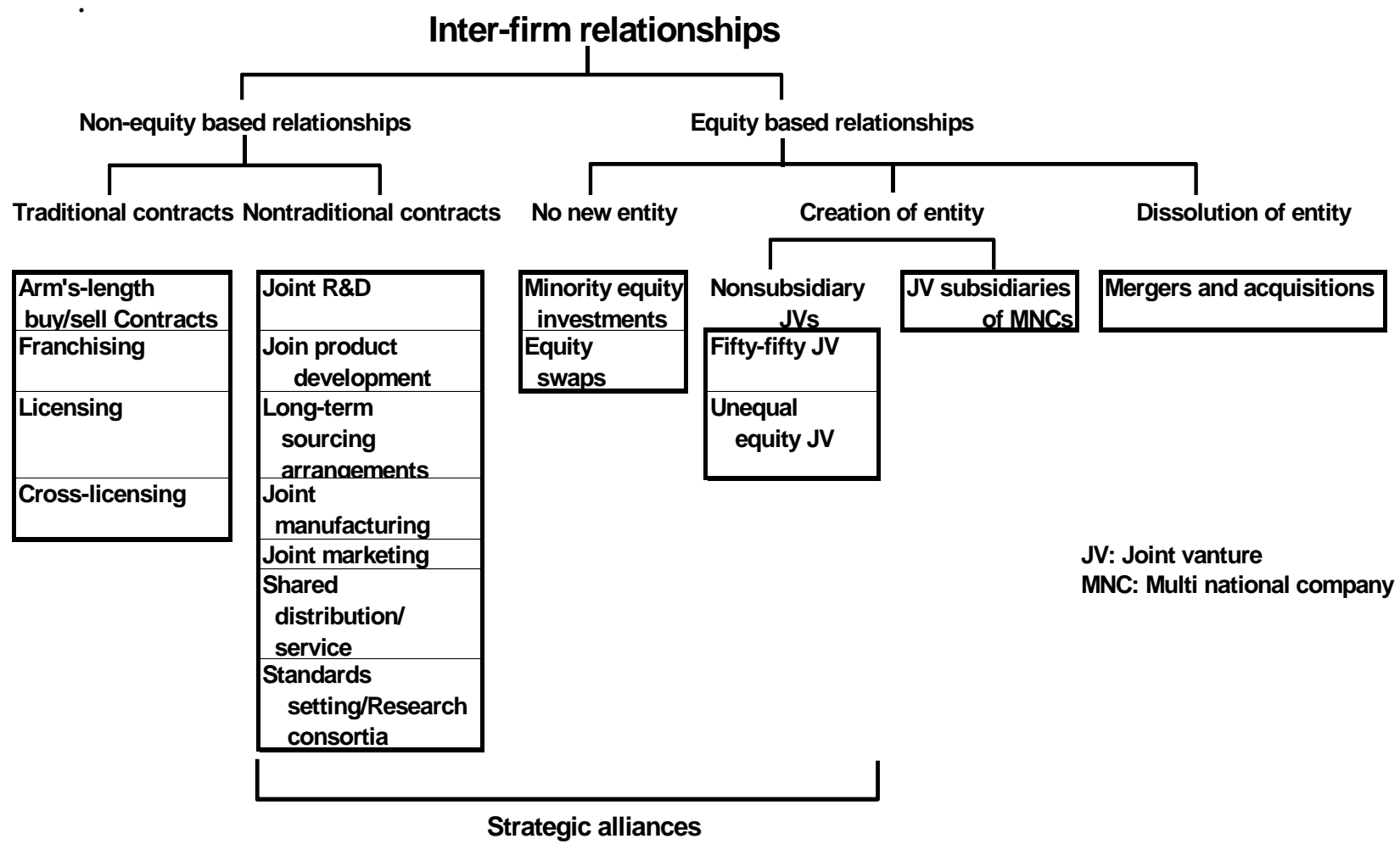

Figure 1 Inter-firm Relationships by Yoshino and Rangan (1995)

Although many researchers have tried to explain a firm's choice of alliance formation based on empirical analysis (Eisenhardt \& Schoonhoven, 1996; Hennart \& Reddy, 1997; Chen \& Chen 2003), there does not seem to be sufficient research based on the theoretical determinations of alliance formation, particularly in the choice of strategic alliances or M\&A in the telecommunications industry. This situation points to the difficulty in explaining factors affecting alliance formation and it is quite challenging to provide a unified explanation.

Furthermore, in research and discussion, strategic alliance, joint venture, and M\&A are usually defined as distinct alternatives; the distinction is well accepted, as Barney (2002) illustrated. Therefore, strategic alliances and other inter-firm 
relationships such as M\&A or equity-based relationships have usually been discussed separately and independently of one another. However, in the telecommunications industry, a different perspective on this categorization may be appropriate.

\section{Characteristics of Relationships}

As discussed in the second section, the industry has two distinctive characteristics: a tendency toward monopolies and the presence of a regulatory environment. These characteristics explain why, relative to companies in other industries, telecommunications firms have less opportunity to acquire competitiveness through strategic means. Therefore, it can be noted that telecommunications firms usually have an incentive to expand their networks. This incentive consequently drives firms to apply strategic activities to their business scales.

Before the introduction of deregulation into the telecommunications market in industrialized countries, strict limitations were in effect in such areas as market entrance, acquisitions, and foreign investments. Therefore, telecommunications firms had few choices in inter-firm relationships during this era. Under such conditions, when a firm intended to expand its network and business scale, one of its few alternatives was to interconnect its network with those of other telecommunications firms. Even after the process of deregulation, this trend continued. In modern times, almost all telecommunications firms' networks are interconnected with those of other telecommunications firms; firms without network interconnection are scarce.

Although such interconnection would not necessarily be defined as a strategic alliance in the context of other industries, network interconnection in the telecommunications industry is one of the most efficient ways for a firm to expand its business and acquire new customers and markets. For this reason, network interconnections can be defined as one type of inter-firm relationship in the telecommunications industry.

In fact, it is easy to find various types of network interconnections among operators of long-distance, international, local, fixed-line, and mobile services. These interconnections are made so that each firm acquires the advantages of network externality.

Network interconnection with a local telephone has always been identified as a major regulatory issue. The basis of the argument is that a local telephone network was always understood to be an essential facility; networks remain dominant because telecommunications operators in most countries started their businesses as primary companies owned or designated by the government (Vogelsang \& Mitchell, 1997). 
After the 1980s, when deregulation was brought into the telecommunications industry in industrialized countries, barriers to entering the market, forming joint sales and ventures, and investing in other telecommunications firms began to be abolished. World Partners (AT\&T, Singapore Telecom, and KDD), Global One (France Telecom, Deutsche Telecom, and Sprint), Concert (British Telecom and MCI), and Unisource (Telia, KPN, Swisscom, and Telefonica) are examples of the outcome of deregulations in industrialized countries.

In addition, Mitchell and Mulherin (1996) suggested that the environment of an industry is strongly related to firms' acquisition or takeover strategies. Schoenberg and Reeves (1999) argued that deregulation is the single most important factor determining acquisition activity at the industry level. Although these researchers do not directly focus on the telecommunications industry, their work may provide suggestions relevant to it.

On the basis of the characteristics of the industry reviewed above, telecommunications firms naturally focus their business growth by network expansion. Research by Mitchell and Mulherin (1996) and Schoenberg and Reeves (1999) implies that the number of equity-based inter-firm relationships will increase as regulatory systems change. Therefore, it can be expected that telecommunications firms naturally aim to expand their networks by establishing inter-firm relationships with their counterparts. They will additionally seek to establish equity-based inter-firm relationships as regulatory systems change.

\section{Trend and Implications of Relationships}

To discuss whether the trend illustrated above is pertinent, we analyzed a selection of actual inter-firm relationships. Cases that occurred from 1980 through 2002 were chosen from the Financial Times article database. Although the selected time frame seems not to cover very recent years, we chose it to cover the period of deregulation movements in the targeted countries discussed in the above sections and in other major countries. To facilitate the observation of industry trends, the selected cases depict telecommunications firms with revenue scales that exceed 100 million U.S. dollars and with headquarters located in OECD countries. The conditions were set because the cases had to be selected in deregulated countries in order to verify the effects of deregulation and ensure the reliability of disclosed information.

Consequently, 121 inter-firm relationships were selected, with all relationships occurring after 1985. The trend in the number of inter-firm relationships and the proportion of equity-based inter-firm relationships within the observed term are shown 
in Table 1. Although sales alliances and joint ventures were conducted after the 1990s, 115 out of 121 cases were equity-based-either investments or M\&A. It can be noted that M\&A or equity-based inter-firm relationships were the main forms of inter-firm relationship in the telecommunications industry throughout the observed term. Furthermore, the number of equity-based inter-firm relationships has increased since the end of the 1990s, which explains that the number of these relationships may be correlated with the trend of deregulation.

Another important phenomenon can be identified - there has been no change in the trend that equity-based inter-firm relationships were most preferred throughout the observed period, within which time several types of dramatic regulatory changes occurred. This phenomenon runs counter to the original expectations based on a regulatory point of view.

In addition, the preference of telecommunications firms for inter-firm relationships differs from conditions in other industries in spite of the existence of a strong regulatory system there. For example, in the airlines industry, various types of inter-firm relationships are clearly defined and actually conducted - such as code sharing, joint marketing, seat arrangements and FFP programs (Rhodes \& Lush, 1997).

On the basis of the above discussions, we propose a model, described in Figure 2 that illustrates the trend of network and business integration in the telecommunications market. This figure shows that the network integration of telecommunications firms evolves from interconnection through joint ventures, equity-based relationships, and finally M\&A, reflecting the state of the regulatory system. With regard to the relationship between Figure 1 and the Figure 2, Figure 1 by Yoshino and Rangan (1995) is representing a static typology of inter-firm relationships at a given environment or condition surrounding firms, while Figure 2 represents a dynamic trend of inter-firm relationships in the telecommunications industry correlated to environment changes in the industry.

Table 1 Inter-firm relationships in the telecommunications industry (equity or non-equity)

\begin{tabular}{lcccccc}
\hline Year & $1980-1984$ & $1985-1989$ & $1990-1994$ & $1995-1999$ & $2000-2002$ & Total \\
\hline Total & 0 & 18 & 20 & 41 & 42 & 121 \\
\hline Equity based & & 18 & 19 & 40 & 38 & 115 \\
\hline Non-equity based & & 0 & 1 & 1 & 4 & 6 \\
\hline
\end{tabular}




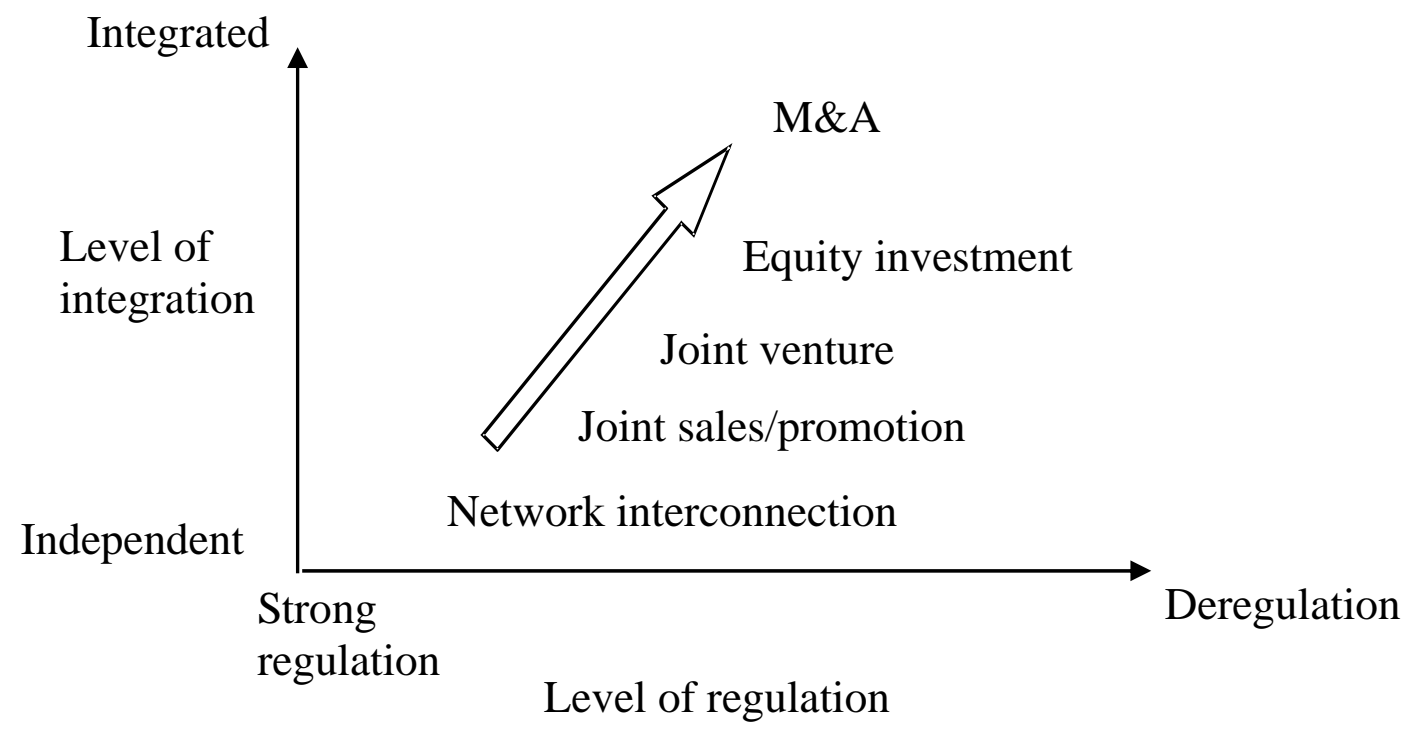

Figure 2 Streamlining inter-firm relationships

\section{TYPOLOGY OF INTER-FIRM RELATIOSHIPS IN THE TELECOMMUNICATIONS INDUSTRY}

\section{Typology of Relationships}

Inter-firm relationships can be categorized in a variety of ways. For example, Yoshino and Rangan (1995) proposed as described Fig.1, and U.S. Federal Trade Commission defines category focused on the direction of M\&A-such as vertical, horizontal, product and market extension, and conglomerate (Barney, 2002). Such typologies could be applicable to the telecommunications industry, but managers and researchers would benefit even more if an additional industry-oriented methodology could be provided. Indeed, several bodies of research have proposed such analytical frameworks.

Graack (1996) described the differences between strategies in European countries, pointing out that national-level competition plays an important role in the international market structure. Joshi et al. (1998) proposed an analytical framework based on the U.S. telecommunications industry but did not extend it to other geographical areas, perhaps because of differences in categorization and coding of the industry. Styliadou (1997) showed an example of a typology for inter-firm relationships of firms based in European countries. 
However, these typologies are mainly aimed at explaining the results of a firm's strategy and activities, and they seem unsuitable as methodologies for managers establishing strategies for inter-firm relationships. Thus, managers and scholars will receive maximum benefit if this paper can provide a different analytical framework for alliances in the telecommunications industry.

We aimed to develop a typology as a combination of several dimensions reflecting the environment and characteristics of the industry and each dimension represents direction along which firms develop strategies for inter-firm relationships. In this regard we recognize that two conditions must be considered in setting a typology of inter-firm relationships. First, the market structure of the telecommunications industry can be set as a key factor for establishing a typology of alliances in the industry. As discussed in previous section, the telecommunications market can be defined as a combination of several categories-local, long-distance and international, and mobile services. Therefore, we insist that a typology reflecting this categorization will provide valuable information about inter-firm relationships in the telecommunications industry. Second, the typology must be consistent with existing theory regarding corporate strategy or inter-firm relationships.

As the aim of forming an inter-firm relationship is to strengthen the ability of firms to compete, discussions by Porter (1985) and Barney (1986, 1991, 2002) provided useful aspects for establishing typology in this research.

The first condition (market structure) provides a framework for basing typology on the area and category of a firm's business, such as fixed or mobile. In other words, a dimension of the typology may be based on the new business area/category that a firm intends to enter.

Elements and factors to be considered in establishing strategies to gain and sustain competitive advantages, have been defined by Porter (1985) and Barney (2002) as cost, differentiation, technologies, and several other aspects. Among the many factors they set forth, the most relevant to market structure is business diversification. The dimension is set as area diversification, with business (within telecommunications) diversification based on market structure. Therefore, it can be recommended that a dimension based on business diversification be set.

Three dimensions corresponding to the directions of strategic relationships can be defined. The first dimension is that a firm may form relationships designed to expand its business size as simply as possible. In this direction, strategic relationships are formed between firms in the same category of the telecommunications market-e.g., mergers between two long-distance firms or two mobile firms-by expanding 
internationally in order to increase the firms' geographical area of business. We call this category geographical expansion.

The second dimension is that relationships can aim to expand a firm's business toward a different category of the market within the telecommunications industry (e.g., a strategic relationship between a long-distance firm and a local or mobile telecommunications firm). In this direction, the firms aim to acquire synergistic effects from the combination of their market knowledge and customer bases with firms that have different business experience. We call this type of direction segment expansion.

The third dimension is that relationships may focus on entry into an adjoining market (e.g., a telecommunications firm entering into a software or content delivery business). This type of relationship aims to acquire a different kind of synergetic effect from the previous two directions. We call this type of direction business diversification.

These three directions are independent of each other and every alliance can be categorized by using these three categories. Therefore, we call this typology the three-dimensional model for the industry (Figure 3). This model will help managers and researchers develop or analyze the strategies of alliances in telecommunications industry. Moreover, the variable of each dimension is observed as 1 (true) or 0 (false) for each relationship and can be defined clearly through observation or from the announcements made by each firm.

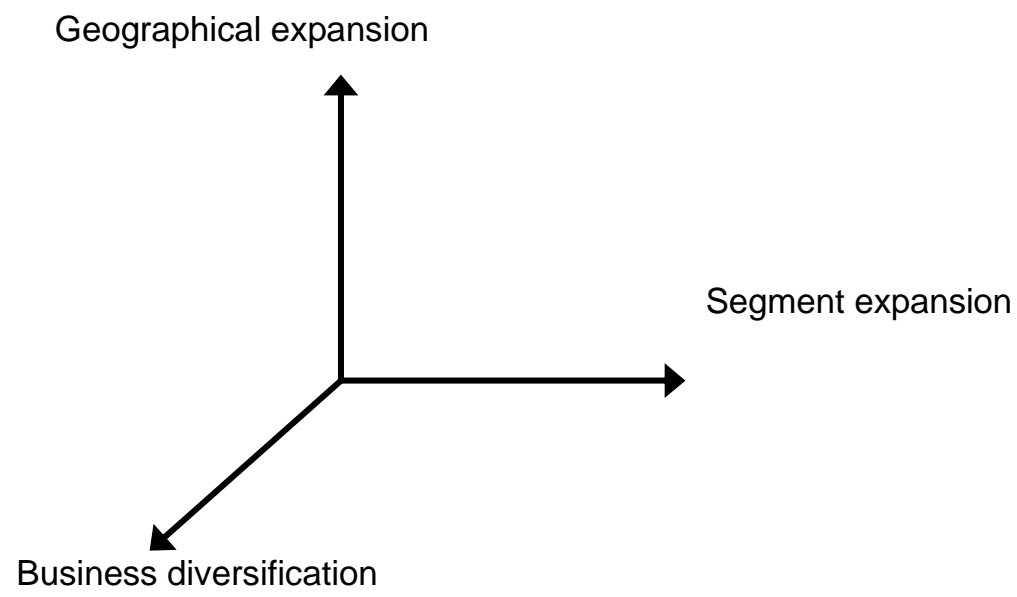

Figure 3 Three-dimensional typology of inter-firm relationships 


\section{Observed Relationships}

This section discusses whether the trend illustrated in sections third section (Inter-firm relationships in the telecommunications industry) and the three-dimensional typology can be explained by actual inter-firm relationships. The 121 inter-firm relationships discussed in section 3.3 are categorized in Table 2 according to our earlier discussion. Using our model, we were able to categorize 43 cases of the 121 inter-firm relationships as geographic expansions, 26 as segment expansion and 50 as business diversification. Only two could not be categorized due to a lack of accurate information about the firms. In addition, it is noted that we did not find any relationship of combination of two or more directions. The results may lead firms to evaluate practicality of forming future inter-firm relationships through analysis based on this proposed typology. A firm will be able to evaluate and compare actual inter-firm relationships conducted by firms through observation based on the typology.

Table 2 Inter-Firm Relationships by Direction

\begin{tabular}{lcccccc}
\hline Year & $1980-1984$ & $1985-1989$ & $1990-1994$ & $1995-1999$ & $2000-2002$ & Total \\
\hline Total & 0 & 18 & 20 & 41 & 42 & 121 \\
\hline $\begin{array}{l}\text { Geographical } \\
\text { expansion }\end{array}$ & 2 & 9 & 16 & 16 & 43 \\
\hline Segment expansion & 1 & 4 & 12 & 9 & 26 \\
\hline $\begin{array}{l}\text { Business } \\
\text { diversification }\end{array}$ & 15 & 8 & 12 & 15 & 50 \\
\hline (Not identified) & & & & & 2 & 2 \\
\hline
\end{tabular}

\section{CONCLUSION AND ISSUES FOR FURTHER RESEARCH}

This research aimed at identifying the characteristics of the telecommunications industry. In particular, in this study, we focused on inter-firm relationships within the industry and proposed a typology for these relationships. In addition, the research included an evaluation of inter-firm relationships based on the typology. There are three contributions of this research.

The first is that it describes the characteristics of the telecommunications industry from the standpoint of the formation of inter-firm relationships. The second is that it presents the characteristics of the forms of inter-firm relationships in this industry and shows that equity-based inter-firm relationships, including M\&A, are the most preferred forms in this industry—-they characterize the nature of the industry. 
Although inter-firm relationships in the industry seem strongly correlated with regulatory systems, preferred inter-firm strategies used by managers seem to have remained the same before and after significant regulatory changes in the telecommunications industry. This phenomenon seems to be different from that observed in other regulated industries, such as the airline and pharmaceutical industries (Rhodes \& Lush, 1997; Achilladelis, \& Antonakis, 2001), where various types of alliances are seen. The phenomenon may therefore be correlated with the nature of the industry, which implies that the formation of inter-firm relationships may not be directly particular to regulatory schemes in the industry so far. The third contribution is that the proposed typology help managers enter into the most appropriate alliance in this industry.

These results have important implications for managers seeking to establish strategies and they offer an example of a framework for scholars who may develop further research.

Although above contribution are provided by the study, some limitations should be recognized. One is the proposed typology is based on the understanding that the businesses of telecommunications carriers usually focused on telecommunications services and not mainly on other businesses. Therefore possibilities of some firm aiming to focus on different area of businesses should be considered. Another issue is that

One of the most important issues to be developed is evaluation of inter-firm relationships. Managers developing strategies for establishing inter-firm relationships must estimate whether a selected strategy will intensify the competitiveness of their firm and whether the market or shareholders will favor the relationship and consequently bring more profit to the firm. Therefore, methodologies for evaluating inter-firm relationships, evaluation of observed inter-firm relationships, and consequently implications for developing inter-firm relationships are the most important issues for further research.

\section{REFERENCES}

Achilladelis, B., \& Antonakis, N. (2001). The dynamics of technological innovation: The case of the pharmaceutical industry. Research Policy, 30, 535-588.

Amesse, F., Latour, R., Rebolledo, C., \& Seguin-Dulude, L. (2004). The telecommunications equipment industry in the 1990s: From alliances to mergers and acquisitions. Technovation. 24(11), 885-897. 
Barney, J. B. (1986). Types of competition and the theory of strategy: Toward an integrative framework. Academy of Management Review, 11, 791-800.

Barney, J. B. (1991). Firm resources and sustained competitive advantage. Journal of Management, 17, 99-120.

Barney, J. B. (2002). Gaining and sustaining competitive advantage ( $2^{\text {nd }}$ ed.). Upper Saddle River, NJ: Prentice Hall.

Baroncelli, A. (1998). Telecom Italia: Merging five companies into one. Long Range Planning, 31, 377-395.

Brock, G. W. (1998). Telecommunications policy for the information age. Cambridge, MA: Harvard University Press.

Chan-Olmsted, S., \& Jamison, M. (2001). Rivalry through alliances: Competitive strategy in the global telecommunications market. European Management Journal, 19, 317-331.

Chen, C. J. (2003). The effects of environment and partner characteristics on the choice of alliance forms. International Journal of Project Management, 21, 115-124.

Chen, H., \& Chen, T. J. (2003). Governance structure in strategic alliances: Transaction cost versus resource-based perspective. Journal of World Business, 38, 1-14.

Crandall, R. W. (1996). Is it time to eliminate telephone regulation? In D. L. Alexander, (Ed.), Telecommunications policy: Have regulators dialed the wrong number? (pp. 17-29). Westport, CT: Praeger.

Curwen, P. (2001). Rivalry through alliances: A rejoinder to Chan-Olmsted and Jamison. European Management Journal, 19, 678- 681.

Das, T. K., \& Bing-Sheng Teng, B. S. (2000). A resource-based theory of strategic alliances. Journal of Management, 26, 31-61.

Doz, Y. L., \& Hamel, G. (1998). Alliance advantage: The art of creating value through partnering. Boston: Harvard Business School Press.

Eisenhardt, K., \& Schoonhoven, C. B. (1996). Strategic alliance formation in entrepreneurial firms: Strategic needs and social opportunities for cooperation. Organization Science, 7, 136-150.

Faulhaber, G. (2002). Network effects and merger analysis: Instant messaging and the AOL-Time Warner case. Telecommunications Policy, 26, 311-333. 
Federal Communications Commission. (1980). Regulatory policies concerning resale and shared use of common carrier domestic public switched network services (CC Docket No. 80-54). Washington, DC: U.S. Government Printing Office.

Garette, B., \& Dussauge, P. (2000). Alliances versus acquisitions: choosing the right option. European Management Journal, 18(1), 63-69.

Graack, C. (1996). Telecom operators in the European Union: Internationalization strategies and network alliances. Telecommunications Policy, 20, 341-355.

Gudmundsson, S. V., \& Rhoades, D. L. (2001). Airline alliance survival analysis: typology, strategy and duration. Transport Policy, 8, 209-218.

Harrison, J. S., Hitt, M. A., Hoskisson, R. E., \& Ireland, R. D. (2001). Resource complementarity in business combinations: Extending the logic to organizational alliances. Journal of Management, 27, 679-690.

Hennart, J. F., \& Reddy, S. (1997). The choice between mergers/acquisitions and joint ventures: The case of Japanese investors in the United States. Strategic Management Journal, 18, 1-12.

Hill, D. C. (1997). Monitoring performance and ensuring quality in drug discovery alliances. DDT, 2(1), 29-33.

Hoffmann, W. H., \& Schlosser, R. (2001). Success factors of strategic alliances in small and medium size enterprises-An empirical study. Long Range Planning, 34, 357-381.

Hopkins, H. D. (1999). Cross-border mergers and acquisitions: Global and regional perspectives. Journal of International Management, 5, 207-239.

Hudson, H. E. (2004). Universal access: What have we learned from the E-rate? Telecommunications Policy, 28, 309-321.

Jamison, M., \& Chan-Olmsted, S. (2002). Rivalry through alliances: Competitive strategy in the global telecoms market. A reply to Curwen. European Management Journal, 20, 95-97.

Joshi, M. P., Kashlak, R. J., \& Sherman, H. D. (1998). How alliances are reshaping telecommunications. Long Range Planning, 21(4), 542-548.

Kahn, A. E. (1997). The economics of regulation. Cambridge, MA: MIT Press.

Laffont, J. J., \& Tirole, J. (2001). Competition in telecommunications. Cambridge, MA: MIT Press.

Mitchell, M. L., \& Mulherin, J. H. (1996). The impact of industry shocks on takeover and restructuring activity. Journal of Financial Economics, 41, 193-229.

Mocker, R. J. (1997). Multinational strategic alliances: A manager's perspective. Strategic Change, 6, 391-405. 
Oh, J. G. (1996). Global strategic alliances in the telecommunications industry. Telecommunications Policy, 20, 713-720.

Peng, M. W. (2001). The resource-based view and international business. Journal of Management, 27, 803-829.

Porter, M. E. (1985). Competitive advantage. New York: The Free Press.

Rhodes, D., \& Lush, H. (1997). A typology of strategic alliances in the airline industry: Propositions for stability and duration. Journal of Air Transport Management, 3(3), 109-114.

Schoenberg, R., \& Reeves, R. (1999). What determines acquisition activity within an industry? European Management Journal, 17, 93-98.

Styliadou, M. (1997). Applying EC competition law to alliances in the telecommunications sector. Telecommunications Policy, 21, 47-58.

Trillas, F. (2002). Mergers, acquisitions, and control of telecommunications firms in Europe. Telecommunications Policy, 26, 269-286.

Vogelsang, I., \& Mitchell, B. M. (1997). Telecommunications competition: The last 10 miles. Washington, DC: The AEI Press.

Wilcox, H. D., Chang, K. C., \& Grover, V. (2001). Valuation of mergers and acquisitions in the telecommunications industry: A study on diversification and firm size. Information and Management, 38, 459-471.

Yasuda, H. (2005). Formation of strategic alliances in high-technology industries: Comparative study of the resource-based theory and the transaction-cost theory. Technovation, 25(7), 763-770.

Yoshino, M. Y., \& Rangan, U. S. (1995). Strategic alliances: An entrepreneurial approach to globalization. Boston: Harvard Business School Press. 